\title{
LUT
}

Lappeenranta

University of Technology

\section{Pulp and Paper Industry in Traditional and New Markets - A Fuzzy Input- Output Analysis}

Hujala Maija, Luukka Pasi, Arminen Heli, Puumalainen Kaisu, Mattila Jorma K.

This is a Final draft version of a publication

published by Inderscience

in International Journal of Procurement Management

DOI: $\quad 10.1504 /$ IJPM.2014.064970

Copyright of the original publication: (c) Inderscience 2014

Please cite the publication as follows:

Hujala, M., Luukka, P., Arminen, H., Puumalainen, K., Mattila, J.K. (2014) Pulp and paper industry in traditional and new markets - A fuzzy input-output analysis. International Journal of Procurement Management, Vol. 7, No. 6:639-660. DOI: 10.1504/IJPM.2014.064970 
The Version of Record of this manuscript has been published and is available in

International Journal of Procurement Management, 2014, Vol. 7, No. 6:639-660.

DOI: https://doi.org/10.1504/IJPM.2014.064970

\title{
(C) Inderscience
}

\section{PULP AND PAPER INDUSTRY IN TRADITIONAL AND NEW MARKETS - A FUZZY INPUT-OUTPUT ANALYSIS}

\section{Maija Hujala*, Pasi Luukka, Heli Arminen, Kaisu Puumalainen, Jorma K. Mattila}

\begin{abstract}
The global business environment of the pulp and paper industry (PPI) has changed drastically during past decades. This paper focuses on analyzing the linkages between PPI and other industries in Brazil, Finland, and the United States. We identified the most important inter-industry linkages and analyzed possible differences between countries, and over time. We also predicted Finland's input-output structure using fuzzy linear models. The results suggest that there are distinct differences across countries and also over time. It seems that the global changes in pulp and paper markets have changed the purchase "recipe" of PPI in all of the countries investigated. Fuzzy input-output analysis was found to be a useful forecast method, although further research is needed prior to any generalizations.
\end{abstract}

Keywords: Input-output analysis, Fuzzy linear systems, Pulp and paper industry 


\section{Introduction}

The pulp and paper industry (PPI) has experienced major structural changes in the 2000s. Examples of the changes include the substitution of printed media for electronic communication technologies, the shift in advertising expenditures from print media to electronic media, innovations in clonal forestry, and the increased importance of China, Brazil, India and other emerging market economies (see, e.g., Figueiredo, 2010; Hurmekoski and Hetemäki, 2013). One consequence is that the production of pulp and paper is gradually moving from the mature markets of North America, Western Europe and Japan to e.g. Southeast Asia and South America, where the demand for paper and board is increasing and cost-effective raw materials are available. In the 2000s, China with its low labor and energy costs and booming paper and board consumption has become a particularly important player in the industry, while several paper machines and mills have been closed in Western Europe, where the industry has suffered from overcapacity and profitability problems (Valtonen, 2008). South America, especially Brazil, has become one of the most important wood pulp exporters due to its eucalyptus plantations (see, e.g., Hujala et al., 2013). Yet another significant structural change is that the operating environment of the PPI has become more complex, crosssectoral and interlinked with other sectors (Hurmekoski and Hetemäki, 2013).

The aim here is to describe the economic impact of the PPI on other industries in three countries (Brazil, Finland and the United States) using Leontief's input-output matrices. The selected countries are important global paper and/or pulp producers at different levels of economic development. We are particularly interested in the potential changes in inter-industry linkages between PPI and other industries, and in the role of the PPI in nation's economy between the mid-1990s and mid-2000. We will also predict Finland's input-output structure for PPI and four other industry sectors in 2010 using fuzzy numbers. To our knowledge, this study is one 
of the first ones to apply fuzzy input-output analysis on real data and to report predictive accuracy of fuzzy Leontief input-output applications.

The next section gives an overview about current megatrends affecting PPI. Section 3 presents the theoretical background of the input-output analysis and fuzzy linear systems. Section 4 gives an overview of the data collection, presents the results of the input-output analyses and discusses the main findings. Section 5 concludes the paper.

\section{Current trends affecting PPI}

Three so called megatrends seem to be of high importance in the PPI markets, that is globalization, technological development and environmental awareness. Some recent studies (Jonsson, 2011; Toppinen et al., 2010; Hetemäki et al., 2010) emphasize the significance of globalization and technological development for the PPI. Sideri (1997, p. 38) gives the following definition of globalization: "Globalization is essentially a process driven by economic forces. Its immediate causes are, in this order, the spatial reorganization of production, international trade and the integration of financial markets." The regional redistribution of production and consumption of pulp and paper products is obvious. The increased importance of emerging markets as producers and consumers is evident as is the decreased importance of North America and Western Europe. Reorganization in the international trade of chemical pulp has occurred as well due to Latin America's recent success in the pulp markets and China's insatiable demand for paper making fibers.

According to Larsen (2006), the most important areas in technological development are information technology, biotechnology, nanotechnology and energy. At least the first two areas are clearly causing structural changes in pulp and paper production and consumption. The 
production of newsprint has collapsed in the United States most likely due to the substitution effect of electronic media and the shift in advertising expenditures from print media to electronic media, and innovations in cloning eucalyptus have greatly helped Latin America to gain its position as one of the leading chemical pulp producers (Figueiredo, 2010).

Increasing environmental awareness also has its impacts on the PPI since producing pulp, paper and paperboard has significant impacts on environment in different stages of the product life cycle (forestry, pulping, bleaching, paper and board manufacturing, transportation etc.) (Frota Neto et al., 2008). For example, recovered paper is nowadays the leading raw material in paper and paperboard production. This development has been facilitated by technological progress, for example, in the areas of deinking and screening of impurities (Diesen, 2007), the good price competitiveness of recycled fiber and Asia’s need for fiber (see. e.g., Arminen et al., 2013). Environmental consciousness and regulation have also contributed to the increase in the demand for recovered paper (see, e.g., Huhtala and Samakovlis, 2002; Samakovlis, 2003; Berglund et al., 2002; Berglund and Söderholm, 2003; Arminen et al., 2013). Moreover, according to Kando and Buongiorno (2009), the efficiency in wood and virgin fiber utilization has increased in most of the OECD countries between 1961 and 2005. The results most likely reflect the significance of conserving scarce forest resources since wood utilization efficiency was lower in countries that have vast forest resources. The impact of environmental issues is not limited to production and the use of paper making fibers: according to Toppinen et al. (2010), increasing awareness of environmental and social issues has led corporate social responsibility to become a high profile issue in the forest industry's foreign direct investments, and Jonsson (2011) notes that chemical pulp producers could manufacture new products in integrated bio-refineries and, hence, profit from the growing bio-energy industry. Also, legislation and risen consumer awareness on environment issues have pressurized companies 
to develop their logistics networks (see, e.g., Frota Neto et al., 2008) and directed them toward green supply chain management and purchasing (see, e.g., Eltayeb and Zailani, 2010; Routroy and Pradhan, 2012; Dubey et al. 2013).

According to Hänninen (2004) there is a growing interest in short-term economic forecasts due to changes in the world's economies. Hänninen (2004) also states that the PPI must be aware of alternate future scenarios when making decisions and, thus, there is a need for forecast models and forecasts. According to the literature review of Toppinen and Kuuluvainen (2010) about the forest sector modeling in Europe, it seems that there are only few econometric studies that have attempted to forecast forest sector development. In addition, the partial equilibrium models most often used to forecast the future of the forest sector do not cope well with the structural changes and uncertainties concerning model parameters (Hurmekoski and Hetemäki, 2013). Therefore, it would be important to perform sensitivity analysis in order to account for the uncertainties (see, e.g., Kallio, 2010).

The first aim of this paper is to analyze whether the megatrends discussed above have affected the inter-industry linkages between PPI and other industries in three different countries. An interesting question is, if all of the trends are equally important. Furthermore, we contribute to the existing literature on short term economic forecasts of forest product sector by predicting Finland's input-output structure for PPI and four other industries in 2010. Fuzzy input-output analysis enables us to take into account some level of uncertainty concerning the input parameters of our model. 


\section{Fuzzy input-output analysis}

The input-output model was originally developed by Wassily Leontief in 1936. It is an analytical tool that can be used in various economic problems such as identifying the key sectors of an economy or revealing possible bottlenecks during the expansion of production (see, e.g., Miernyk, 1965). The input-output analysis is based on the data organized in the form of a table illustrating the structure of a nation's (or region's) economy at a given point in time. The input-output table depicts the volumes of purchases and sales among industries. Thus, it shows how dependent each industry is on all the other industries in the economy.

The structure of an input-output table is illustrated by Table 1 .

[Table 1 near here]

Each row of the input-output table reports the value of the industry's outputs, and the inputs are represented in the columns. Non-industrial inputs, such as the compensation for employees (LABR) and gross operating surplus (GOS) are aligned below the matrix. An array of column vectors called final demands, such as the household's final consumption (HHFC), changes in inventories (CHINV) and exports (EXP) are on the right hand side of the matrix. The total gross output of the industry $n$ equals its total input.

The basic equations of the input-output model can be expressed as follows (e.g., Miernyk, 1965). The total gross output $x_{i}$ of an industry is the sum of its intermediate outputs $x_{i j}$ and the final demand $d_{i}$ :

$$
x_{i 1}+x_{i 2}+\cdots+x_{i n}+d_{i}=x_{i} .
$$


The sum of intermediate outputs equals the total volume of sales from the industry in question to other industries. Final demand $d_{i}$ captures the direct sales from the industry to households, nonprofit institutions and general government, plus the sum of gross fixed capital formation, changes in inventories, valuables and exports. Imports are either subtracted from the exports (so-called total input-output tables) or they are seen as inputs to the industry (so-called domestic input-output tables).

An important concept related to the input-output analysis is the technical coefficient. These coefficients represent the direct purchases of each industry from every other industry per one monetary unit of output. For example, in 2005 Brazilian PPI purchased from chemical industry for \$0.081 and from forest industry for \$0.059 per one US dollar of output. Thus, in a sense, the technical coefficients are the recipe used in an industry.

Based on Table 1, the technical coefficients are calculated as

$$
a_{i j}=\frac{x_{i j}}{x_{j}}
$$

Substituting (2) in (1) yields

$$
a_{i 1} x_{1}+a_{i 2} x_{2}+\cdots+a_{i n} x_{n}+d_{i}=x_{i}
$$

In matrix form we have

$$
\mathbf{A} x+d=x
$$


where $\mathbf{A}=\left[a_{i j}\right], x=\left[x_{i}\right]$ and $d=\left[d_{i}\right]$. The matrix $\mathbf{A}$ is called the technological (or input-output or consumption) matrix of the economy. Solving for $x$ we obtain

$$
x=(\mathbf{I}-\mathbf{A})^{-1} d
$$

where (I-A) $)^{-1}$ is called the Leontief inverse matrix. If the technological matrix $\mathbf{A}$ is known and does not change over the projection period, we can use equation (5) to predict the vector of total output $x$ and, for example, new inter-industry transactions $x_{i j}$ resulting from changes in the final demand vector $d$.

Over a long time span, the technical coefficients (equation (2)) will be affected by four kinds of changes: changes in the relative prices of inputs, appearance of new industries, changes in the product mix of a particular industry (Davis et al., 1977) and technological change (Miernyk, 1965). The early input-output-studies demonstrated empirically the change of technical coefficients (Leontief, 1953; Carter, 1967) and suggested methods for updating the technical coefficients without having to rely on time- and resource-intensive survey-based aggregation of the input-output tables. Among the most prominent and widely applied updating methods are the RAS method (Bates and Bacharach, 1963) and linear programming (Matuszewski et al., 1964). RAS has been shown to be superior at both regional and national level (Davis et al., 1977). A disadvantage of both methods is that they require a lot of input data: 1) the coefficient matrix A for a base year, 2) vector of gross outputs of each industry for the target year, 3) vector of intermediate outputs and 4) vector of intermediate inputs. In addition, they are purely mechanical routines not allowing for informed judgment regarding changes in the coefficients 
of interest. However, more recent evidence implies that judgment-based methods like Delphi could provide reliable and valid information for input-output analysis (Landeta et al., 2008).

The early updating methods also present the results as point estimates, failing to take into account the probabilistic nature of the input coefficients (West, 1986). Buckley (1989) introduced a method to incorporate fuzzy numbers in input-output analysis, and theoretically derived the conditions for the fuzzy model to exist. The advantage of this method over the more traditional approaches to updating the technical coefficients is that the vectors of final demand and sums of intermediate outputs and inputs do not need to be known exactly. More recently, Beynon et al. (2005) and Beynon and Munday (2006) further developed the fuzzy input-output analysis of Buckley (1989). Sevastjanov and Dymova (2009), Mattila and Luukka (2009), Luukka and Mattila (2009) as well as Dymova et al. (2013), also examined fuzzy methods in Leontief input-output analysis.

The underlying idea in this paper is that when solving an input-output model we assume both final demand $d$ and the technological matrix A to be fuzzy. This is based on the assumption that, in both demand vector and technical coefficients, there is a certain level of uncertainty. Hence, when solving the total output it will inherit this uncertainty as well. Here, we approach this problem with the tools mainly introduced in (Mattila and Luukka, 2009) and (Luukka and Mattila, 2009) coming from fuzzy logic. 
We consider the following fuzzy linear system:

$$
\begin{aligned}
& a_{11} x_{1}+a_{12} x_{2}+\cdots+a_{1 n} x_{n}=b_{1} \\
& a_{21} x_{1}+a_{22} x_{2}+\cdots+a_{2 n} x_{n}=b_{2} \\
& \vdots \\
& a_{n 1} x_{1}+a_{n 2} x_{2}+\cdots+a_{n n} x_{n}=b_{n}
\end{aligned}
$$

or in matrix format $\mathbf{A x}=b$, where $\mathbf{A}=\left[a_{i j}\right]$ and $b=\left[b_{i}\right]$ are considered to be fuzzy numbers instead of crisp values. The same applies of course also for (I-A) $x=d$.

The Jacobi method for solving this linear system is

$$
x_{i}^{k+1}=\frac{1}{a_{i i}}\left(b_{i}-\sum_{\substack{j=1 \\ j \neq i}}^{n} a_{i j} x_{j}^{k}\right)
$$

It is an iterative algorithm for determining the solutions of the system of linear equations. In our approach, the addition, subtraction, multiplication and division operations are coming from fuzzy logic (Dubois and Prade, 1980). The idea for solving fuzzy linear systems in this manner is introduced in (Mattila and Luukka, 2009) and (Luukka and Mattila, 2009) for the GaussSeidel and the successive over relaxation (SOR) algorithm. Here we use the Jacobi method because of its nice convergence properties.

We use the left-right (LR) -type fuzzy numbers, which can be written as

$$
\mu_{A}(x)=\left\{\begin{array}{lll}
L((M-x) / l) & \text { if } & x \leq M \\
R((x-M) / r) & \text { if } & x \geq M
\end{array}\right.
$$


for $l>0$ and $r>0$. For LR-type function, we use $L(x)=R(x)=\max [1-x, 0]$, so that we are basically dealing with triangle type fuzzy numbers. LR-type fuzzy numbers can be expressed using the modal value $M$, the left support length $l$, and the right support length $r$ as $A=(M, l$, r).

In order to apply the Jacobi method, we need the extended sum, difference, product and division for fuzzy numbers. The extended sum is

$$
A_{1}+A_{2}=\left(M_{1}+M_{2}, l_{1}+l_{2}, r_{1}+r_{2}\right)
$$

and the extended difference is

$$
A_{1}-A_{2}=\left(M_{1}-M_{2}, l_{1}+r_{2}, r_{1}+l_{2}\right) .
$$

The extended product is:

For $M_{1}>0$ and $M_{2}>0$

$$
A_{1} \cdot A_{2}=\left(M_{1} M_{2}, M_{1} l_{2}+M_{2} l_{1}-l_{1} l_{2}, M_{1} r_{2}+M_{2} r_{1}+r_{1} r_{2}\right),
$$

for $M_{1}<0$ and $M_{2}>0$

$$
A_{1} \cdot A_{2}=\left(M_{1} M_{2}, M_{2} l_{1}-M_{1} r_{2}+l_{1} r_{2}, M_{2} r_{1}-M_{1} l_{2}-r_{1} l_{2}\right) \text {, }
$$


for $M_{1}>0$ and $M_{2}<0$

$$
A_{1} \cdot A_{2}=\left(M_{1} M_{2}, M_{1} l_{2}-M_{2} r_{1}+l_{2} r_{1}, M_{1} r_{2}-M_{2} l_{1}-r_{2} l_{1}\right)
$$

and for $M_{1}<0$ and $M_{2}<0$

$$
A_{1} \cdot A_{2}=\left(M_{1} M_{2},-M_{2} r_{1}-M_{1} r_{2}-r_{1} l_{2},-M_{2} l_{1}-M_{1} l_{2}+l_{1} r_{2}\right)
$$

See more about these product rules in (Dubois and Prade, 1980).

The extended division for $M_{1}>0$ and $M_{2}>0$ is

$$
\frac{A_{1}}{A_{2}}=\left(\frac{M_{1}}{M_{2}}, \frac{r_{2} M_{1}+l_{1} M_{2}}{M_{2}^{2}}, \frac{l_{2} M_{1}+r_{1} M_{2}}{M_{2}^{2}}\right) .
$$

Similarly, other formulas for divisions can be derived when $\mathrm{M}_{1}$ and/or $\mathrm{M}_{2}$ are negative. For more about this, see (Dubois and Prade, 1980).

Although updating technical coefficients by using fuzzy numbers is not a novel idea and various fuzzy techniques have been applied to Leontief input-output models, it appears that empirical studies with real data have not yet been reported in the academic literature. Also, reporting the predictive accuracy of fuzzy Leontief input-output applications is rare. This paper attempts to narrow the research gap by applying fuzzy input-output analysis to OECD’s 2005 
input-output tables to predict Finland's five sector input-output structure in 2010. The predictive accuracy of our method is examined by forecasting Finland's 2010 figures based on OECD’s 1995 and 2000 input-output data as well.

\section{Empirical results}

In this section, we apply comparative analysis of inter-industry purchases and sales as well as the fuzzy input-output model presented in section 3. We first describe the inter-industry linkages between PPI and the other industries in Brazil, Finland and the United States. We are especially interested in the potential differences between the countries and the changes in the technical coefficients and inter-industry linkages between 1995 and 2005. Finally, we predict the structure of inputs and outputs of the PPI, and other industries closely related to it, in Finland in 2010.

\subsection{Data collection}

The input-output tables (Total tables) for Brazil, Finland and the United States were collected from the OECD’s Structural Analysis Database (OECD, 2013). The database includes national input-output tables for three years (1995, 2000 and 2005) and 48 countries in current national currency and US dollars. Input-output tables from all the available years were used in this study. The volumes of purchases and sales were converted to constant 2005 US dollars by deflating with the GDP deflator before the analyses.

OECD’s input-output tables include 37 industries. Unfortunately, the PPI is aggregated with the printing and publishing industries in them. We thus examined some more disaggregated input-output tables provided by Statistics Finland and Instituto Brasileiro de Geografia e 
Estatística. As a result, we were able to limit our analyses to the industries that are more likely linked with the PPI than printing and publishing industry.

\subsection{Results and discussion}

\subsubsection{Inter-industry linkages in Brazil, Finland and the United States}

Tables 2 - 4 show the volume of purchases from other industries by the pulp, paper, printing and publishing industry in Brazil, Finland and the United States. Correspondingly, tables 5 - 7 show the volume of sales by the pulp, paper, printing and publishing industry to other industries. The ten largest sellers and purchasers are depicted. The technical coefficients (in Tables 2 to 4), non-industrial inputs (in Tables 2 to 4), the final demand sector (in Tables 5 to 7) and total gross output are shown as well. Non-industrial inputs include gross operating surplus (GOS), compensation of employees (LABR) and net taxes on production (TAXES). The final demand sector incorporates final consumption by households, non-profit organizations and government (HNG), gross fixed capital formation, i.e., investments (GFCF), changes in inventories (CINV), exports (EXPORT) and imports (IMPORT). All monetary values are expressed in 2005 US dollars. This comparative analysis focuses on the linkages between the PPI and other industries, while the linkages more likely related to the printing and publishing industry are mainly ignored.

[Table 2 near here]

[Table 3 near here]

[Table 4 near here]

There are many differences but also some similarities across the three countries. First of all, it is evident that the technical coefficients have changed between 1995 and 2005 in all three 
countries. Also, technical coefficients differ between the countries. The PPI is by far the largest purchaser of its own products in all of the countries. This is due to pulp that is bought as an input to the paper and board production processes. In addition to the volume of paper and board production, the volume of intra-industry purchases depends on pulp prices and the availability and price of recovered paper, which is also an important raw material in paper and board production (see, e.g., Arminen et al., 2013).

Large amounts of chemicals are used in pulp and paper manufacturing. Chemicals and chemical products industry is the second largest seller in Brazil and among the largest ones in Finland and in the United States. The PPI's purchases from the chemical industry almost doubled in Brazil between 1995 and 2005. This is consistent with the rapidly increased production of wood pulp from eucalyptus trees (see, e.g., Hujala et al., 2013). Instead, in Finland purchases from the chemical industry increased between 1995 and 2005 and decreased between 2000 and 2005. In the United States, purchases from the chemical industry have declined since 1995. Thus, it seems that the volume of the purchases from the chemical industry is linked to the upwards and downwards of the PPI. Also, the direct purchases from forestry and transport industries seem to follow the volumes of pulp and paper production. In contrast to Brazil and Finland, forestry is not among the top ten sellers in the United States and is thus not included in Table 4.

The wholesale and retail trade industry includes, among others, the wholesale of waste and scrap, such as waste paper. The volume of purchases from the wholesale industry declined in all of the countries between 2000 and 2005. However, a significant part of the purchases from the wholesale and retail is linked to the printing and publishing industry, so that this result is somewhat uncertain. 
The volume of purchases from electricity, gas and water supply industry increased in Brazil between 1995 and 2005. This is consistent with the mounting paper and board production. On the contrary, in Finland, the purchases from the electricity industry decreased between 1995 and 2000 and increased between 2000 and 2005. The opposite trend between electricity purchases and paper and board production in Finland may be a consequence of changes in electricity prices. According to International Energy Agency’s electricity price database, Finnish electricity end-user prices decreased between 1995 and 2000 and increased between 2000 and 2005. In the United States, electricity industry is not among the top ten sellers.

Purchases from machinery and equipment industry declined in Brazil between 2000 and 2005. The technical coefficients $a_{i j}$ of machinery and equipment industry declined as well. The machinery and equipment industry includes, among others, manufacturing of machinery especially designed for the PPI as well as manufacturing of more general purpose machinery. It thus seems that the number of new pulp and paper mills and/or machines decreased between 2000 and 2005. Instead, in Finland, both purchases and technical coefficients increased between 1995 and 2005.

As shown in Table 4, in the United States $R \& D$ was the third largest seller to the pulp, paper printing and publishing industry in 2000 and 2005. Thus, it seems that, either the PPI has reacted to declining markets by increasing its $R \& D$ investments, or $R \& D$ industry is linked with printing and publishing industry, not with the PPI. In Finland, the importance of R\&D increased between 1995 and 2005 as well, although it is nowhere near the top ten sellers.

[Table 5 near here] 
[Table 6 near here]

[Table 7 near here]

Most of the industries in tables 5-7 are more closely linked with printing and publishing than the PPI. According to our knowledge, only food industry, chemical industry, real estate activities, as well as wholesale in Brazil, are important buyers of PPI products. In Finland and in the United States, there are no significant changes in the sales from pulp, paper, printing and publishing industry to these industries measured as the percentage of total gross output. The same applies to chemical industry in Brazil. Instead, the role of food industry and wholesale has declined in Brazil between 2000 and 2005.

In Brazil and the United States, the total intermediate consumption (TIC) accounted for about 70\%, and private and public consumption (HNG) for about $20 \%$ of the total output in 2005 indicating that the domestic consumption is the main driver of the PPI’s gross output (although the importance of exports has increased in Brazil). In Finland, the PPI is highly dependent on exports, which accounted for $50 \%$ of the gross output in 2005 . Thus, the main driver is foreign demand (Europe's demand for paper and board, to be precise, since paper and board is consumed near the production (e.g. Valtonen, 2008).

\subsubsection{Finland's input-output structure in 2010}

Based on the analysis above, we adopted pulp and paper exports and imports as well as forestry imports as the major driving forces of changes in transactions between the PPI and other industries in Finland. We proposed two final demand scenarios, A (pessimistic) and B (optimistic), based on these driving forces and forecasted Finland's input-output structure in 2010. 
We limited our analysis to five industry sectors: agriculture, hunting, forestry and fishing (forestry); wood and products of wood and cork (wood); pulp, paper, paper products, printing and publishing (pulp, paper), electricity, gas and water supply (electricity) and other industries (other). Table 8 presents Finland's aggregated five sector input-output tables in 1995, 2000 and 2005.

[Table 8 near here]

As shown in Table 8, purchases from the forestry and wood products industries by the electricity industry increased rapidly between 1995 and 2005. Thus, more and more wood material is used in energy production in Finland. In the future, the energy use of wood fiber is likely to continue rising if demand for biofuels grows vastly (see, e.g., Alcamo et al., 2005).

\subsubsection{Final demand scenarios}

At first, it was necessary to determine estimates of the final demand components (private and public consumption, investments, changes in inventories, exports and imports). We based our estimations on various data sources, such as Finnish Statistical Yearbook of Forestry by Finnish Forest Research Institute, ForesSTAT database by FAO, Preliminary Energy Statistics 2009 by Statistics Finland and Country Statistics database by MarketLine. Estimates are shown in Table 9.

[Table 9 near here] 
Scenarios for final demand were then calculated based on Table 9 by subtracting imports from the sum of HNG, GFCF, CHINV and exports. Final demand scenarios are presented in Table 10.

[Table 10 near here]

\subsubsection{Predictions of total output and inter-industry transactions for 2010}

As shown in section 4.2.1, the technical coefficients of the PPI are not constant but change over time. Thus, we applied the fuzzy input-output model presented in Section 3 to predict total outputs and inter-industry transactions in 2010.We used fuzzy technical coefficients $a_{i j}$ and fuzzy demand vector $d$, during the analyses. The uncertainty of $a_{i j}$ and $d$ was assumed to be 4 $\%$. This basically means that, for example, if we have a crisp value $y=100$, our fuzzy value is $y=[1000.04 * 1000.04 * 100]=[10044]$. Thus, the left-hand corner value of the fuzzy triangle is 96, the modal value is 100 and the right-hand corner value is 104 .

Fuzzy total outputs for the final demand vectors A and B are presented in Table 11 and Figure 1. Fuzzy inter industry transactions that would be needed to sustain the projected levels of final demand are presented in Table 12.

[Table 11 near here]

[Figure 1 near here]

[Table 10 near here]

As shown in Table 11 and Figure 1, total output of industries increased between 2005 and 2010 except for the PPI in scenario A. The fuzzy triangles of total output of forestry are almost 
identical between scenarios A and B, and the triangles of wood products industry, electricity industry and other industries overlap as well. It thus seems that drastic changes in PPI exports and forestry imports do not cause large changes in output of other industries

In scenario A, the PPI's purchases from other industries decreased by approximately $10 \%$ compared to the year 2005, and, respectively, increased by $10 \%$ in scenario B. Hence, changes in final demand are almost fully transferred to direct purchases from other industries. Intraindustry purchases of forestry increased in both of the scenarios compared to the year 2005 indicating that Russian roundwood is replaced by domestic roundwood. Sales from forestry and wood products industry to electricity industry are approximately the same in scenarios A and B. Thus, it seems that there is no competition for wood fiber between energy use and pulp and paper manufacturing at this point. Instead, pulp and paper production complements energy use, since, for example, mill residues and harvesting residues are biomass sources for energy production (Nurmi, 2007). According to Raunikar et al. (2010), industrial roundwood will not began to be used for energy production until the real price of fuelwood will converge towards the industrial roundwood as a result of high demand for biofuels.

\subsubsection{Prediction accuracy}

In order to evaluate the accuracy of our projections, we estimated year 2005 total outputs by using 1995 and 2000 technical coefficients $a_{i j}$ and the real 2005 final demand vector. We compared the results with observed 2005 outputs added with 4\% uncertainty. Observed and predicted fuzzy triangles of total output are presented in Appendix. As shown, observed and predicted triangles overlap pretty nicely. Thus, it seems that in this study, $4 \%$ uncertainty in technical coefficients was enough to cover their change over time. 


\section{Conclusions}

In this paper, we first identified the most important inter-industry linkages between the PPI and other industries in Brazil, Finland and the United States. All three countries are important players in the global pulp and/or paper markets. However, they are at different stages of economic development. Brazil is a newcomer in the global pulp markets but has increased its importance as a global pulp producer considerably since the late-1990s. In contrast, Finland and the United States are old paper and pulp producers and exporters and have suffered from stagnating markets in Western Europe and North America.

Our focus was on the differences in the inter-industry relationships between the countries as well as on the changes in the linkages between industries over time. According to our results, there are significant differences in the inter-industry linkages between Brazil, Finland and the United States, and also over time. The structure of direct purchases from other industries by the PPI has clearly changed between the mid-1990s and mid-2000. Instead, the sales from the PPI to other industries have remained relatively constant over time. It thus appears that the megatrends shaping PPI’s operating environment have altered the technical coefficients, i.e. the "recipe", of the PPI in all three countries investigated, although the aggregation of the PPI with the printing and publishing industry slightly disturbed our interpretations (especially with the United States). Overall, globalization seems to have been the most significant trend behind the changes in the "recipe". The impact of global changes in pulp and paper markets on interindustry linkages was seen in all of the sample countries. Instead, technological development and environmental awareness seem to have had less prominent role.

The other objective of this paper was to apply fuzzy linear systems in predicting Finland's input-output structure for the PPI and four other industries - forestry, wood, electricity and 
other - in 2010. We proposed two final demand scenarios: a pessimistic one and an optimistic one, and used fuzzy technical coefficients based on 2005 figures as well as fuzzy final demand vector in our analysis. Rather surprisingly, pessimistic and optimistic scenarios resulted in drastically different outputs of the PPI but with the other industries the differences in outputs between scenarios were barely notable. Thus, our results seem to indicate that the role of the PPI in the total output of the other industries is relatively small in Finland.

Due to structural changes in the input and output markets of PPI it is particularly important to take into account possible uncertainties and perform sensitivity analysis when forecasting forest product sector development. Fuzzy input-output analysis with $4 \%$ uncertainty in technical coefficients and final demand vector was found to be a useful and fairly accurate forecast method in this study. However, more analyses with real data as well as comparisons with traditional methods for updating technical coefficients are needed prior to drawing further conclusions. 


\section{References}

Alcamo, J., van Vuuren, D., Ringer, C., Cramer, W., Masui, T., Alder, J. and Schulze, K. (2005) 'Changes in nature's balance sheet: Model-based estimates of future worldwide ecosystem services’, Ecology and Society, Vol. 10, No. 2, pp.1-19.

Arminen, H., Hujala, M., Puumalainen, K., Tuppura, A. and Toppinen, A. (2013) 'An update on inter-country differences in recovery and utilization of recycled paper', Resources, Conservation and Recycling, Vol. 78, No. 1, pp.124-135.

Berglund, C. and Söderholm, P. (2003) 'An econometric analysis of global waste paper recovery and utilization’, Environmental and Resource Economics, Vol. 26, No. 3, pp.429456.

Berglund, C., Söderholm, P. and Nilsson, M. (2002) 'A note on inter-country differences in waste paper recovery and utilization’, Resources, Conservation and Recycling, Vol. 34, No. 3, pp.175-191.

Beynon, M.J., and Munday, M. (2006) 'The elucidation of multipliers and their moments in fuzzy closed Leontief input-output systems’, Fuzzy Sets and Systems, Vol. 157, No. 18, pp.2482-2494.

Beynon, M.J., Munday, M. and Roberts, A. (2005) 'Ranking sectors using fuzzy multipliers', Economis Systems Research, Vol. 17, No. 3, pp.237-253.

Buckley, J.J. (1989) 'Fuzzy input-output analysis', European Journal of Operational Research, Vol. 39, No. 1, pp.54-60.

Carter, A.P. (1967) 'Changes in the structure of the American economy, 1947 to 1958 and 1962', The Review of Economics and Statistics, Vol. 49, No. 2, pp.209-224.

Davis, H.C., Lofting, E.M. and Sathaye, J.A. (1977) 'A comparison of alternative methods of updating input-output coefficients’, Technological Forecasting and Social Change, Vol. 10, No. 1, pp.79-87.

Diesen, M. (2007) Paper Making Science and Technology Book 1 - Economics of the Pulp and Paper Industry, Paperi ja Puu Oy, Jyväskylä, Finland.

Dubey, R., Bag, S., Ali, S.S. and Venkatesh, V.G. (2013) 'Green purchasing is key to superior performance: an empirical study', International Journal of Procurement Management, Vol. 6, No. 2, pp.187-210.

Dubois, D. and Prade, H. (1980) Fuzzy Sets and Systems: Theory and Applications, Academic Press, New York, NY, 393 p.

Dymova, L., Sevastjanov, P. and Pilarek, M. (2013) 'A method for solving systems of linear interval equations applied to the Leontief input-output model of economics', Expert Systems with Applications, Vol. 40, No. 1, pp.222-230. 
Eltayeb, T.K. and Zailani, S. (2010), 'Investigation on the drivers of green purchasing towards environmental sustainability in the Malaysian manufacturing sector', International Journal of Procurement Management, Vol. 3, No. 3, pp.316-337.

Figueiredo, P.N. (2010) 'Discontinuous innovation capability accumulation in latecomer natural resource-processing firms', Technological Forecasting and Social Change, Vol. 77, No. 7, pp.1090-1108.

Frota Neto, J.Q., Bloemhof-Ruwaard, J.M., van Nunen, J.A.E.E. and van Heck, E. (2008) 'Designing and evaluating sustainable logistics networks', International Journal of Production Economics, Vol. 111, No. 2, pp.195-208.

Hänninen, R. (2004) Editorial - 'Econometric models in forest sector forecasting', Journal of Forest Economics, Vol. 10, No. 2, pp.57-59.

Hetemäki, L., Mery, G., Holopainen, M., Hyyppä, J., Vaario, L.-M. and Yrjälä, K. (2010) 'Implications of technological development to forestry', in Mery, G., Katila, P., Galloway, G., Alfaro, R.I., Kanninen, M., Lobovikov, M. and Varjo, J. (eds.), Forests and Society Responding to Global Drivers of Change, IUFRO World Series, Vol. 25, IUFRO, Vienna, pp.157-181.

Huhtala, A. and Samakovlis, E. (2002) 'Does international harmonization of environmental policy instruments make economic sense?', Environmental and Resource Economics, Vol. 21, No. 3, pp.261-286.

Hujala, M, Arminen, H., Hill, R.C. and Puumalainen, K. (2013) 'Explaining the shifts of international trade in pulp and paper industry’, Forest Science, Vol. 59, No. 2, pp.211-222.

Hurmekoski, E. and Hetemäki L. (2013) 'Studying the future of the forest sector: Review and implications for long-term outlook studies’, Forest Policy and Economics, Vol. 34, September 2013, pp.17-29.

Jonsson, R. (2011) 'Trends and possible future developments in global forest-products markets - Implications for the Swedish forest sector', Forests, Vol. 2, No. 1, pp.147-167.

Kallio, A.M.I. (2010). 'Accounting for uncertainty in a forest sector model using Monte Carlo simulation’, Forest Policy and Economics, Vol. 12, No. 1, pp.9-16.

Kando, H. and Buongiorno, J. (2009) 'Efficiency in wood and fiber utilization in OECD countries’, Journal of Forest Research, Vol. 14, No. 6, pp.321-327.

Landeta, J., Matey, J., Ruiz, V. and Galter, J. (2008) 'Results of a Delphi survey in drawing up the input-output tables for Catalonia', Technological Forecasting and Social Change, Vol. 75, No. 1, pp.32-56.

Larsen, G. (2006) ‘Why megatrends matter’, FO/futureorientation, 5/2006, pp.8-13.

Leontief, W.W. (1936) 'Quantitative input and output relations in the economic system of the United States’, The Review of Economics and Statistics, Vol. 18, No. 3, pp.105-125. 
Leontief, W.W. (1953) Studies in the Structure of the American Economy, Oxford University Press, New York, NY, 561 p.

Luukka, P. and Mattila, J.K. (2009) 'Fuzzy linear systems applied to Leontief input-output model', Acta Technica Jaurinensis - Series Intelligentia Computatorica, Vol. 2, No. 2, pp.249264.

Mattila, J.K. and Luukka, P. (2009) 'Solving Leontief input-output model with fuzzy entries', proceedings of the IEEE International Conference on Fuzzy Systems, FUZZ-IEEE 2009, Jeju Island, South Korea.

Matuszewski, T.I., Pitts, P.R. and Sawyer, J.A. (1964) 'Linear programming estimates of changes in input coefficients', The Canadian Journal of Economics and Political Science, Vol. 30, No. 2, pp.203-210.

Miernyk, W.H. (1965) The Elements of Input-Output Analysis, Random House, New York, NY, 156 p.

Nurmi, J. (2007) 'Recovery of logging residues for energy from spruce (Pices abies) dominated stands’, Biomass and Bioenergy, Vol. 31, No. 6, pp.375-380.

OECD (2013) OECD Structural Analysis (STAN) database, Available at: http://stats.oecd.org/Index.aspx.

Raunikar, R., Buongiorno, J., Turner, J.A. and Zhu, S. (2010) 'Global outlook for wood and forests with the bioenergy demand implied by scenarios of Intergovernmental Panel on Climate Change', Forest Policy and Economics, Vol. 12, No. 1, pp.48-56.

Routroy, S. and Pradhan, S.K. (2012) 'Framework for green procurement: a case study', International Journal of Procurement Management, Vol. 5, No. 3, pp.316-336.

Samakovlis, E. (2003) 'The Relationship between waste paper and other inputs in the Swedish paper industry', Environmental and Resource Economics, Vol. 25, No. 2, pp.191-212.

Sevastjanov, P. and Dymova, L. (2009) 'A new method for solving interval and fuzzy equations: Linear case’, Information Sciences, Vol. 179, No. 7, pp.925-937.

Sideri, S. (1997) 'Globalization and regional integration', in Kay, C. (ed.), Globalisation, Competitiveness and Human Security, Frank Cass \& Co., London, pp.38-82.

Stone, R., Bates, J. and Bacharach, M. (1963) A Programme for Growth Vol. 3 - Input-output relationships 1954-1966, M.I.T. Press, Cambridge, MA, 81 p.

Toppinen, A. and Kuuluvainen, J. (2010) 'Forest sector modelling in Europe - The state of the art and future research directions', Forest Policy and Economics, Vol. 12, No. 1, pp.2-8.

Toppinen, A., Zhang, Y., Geng, W., Laaksonen-Craig, S., Lähtinen, K., Li, N., Liu, C., Majumdar, I. and Shen, Y. (2010) 'Changes in global markets for forest products and timberlands’, in Mery, G., Katila, P., Galloway, G., Alfaro, R.I., Kanninen, M., Lobovikov, M. 
and Varjo, J. (eds.), Forests and Society - Responding to Global Drivers of Change, IUFRO World Series, Vol. 25, IUFRO, Vienna, pp.137-156.

Valtonen, K. (2008) 'Production and exports in the pulp and paper industry', in Hänninen, R. and Sevola Y. (eds.), Finnish Forest Sector Economic Outlook 2008-200, Finnish Forest Research Institute, Vantaa, Finland, pp.19-22.

West, G.R. (1986) 'A stochastic analysis of an input-output model', Econometrica, Vol. 54, No. 2, pp.363-374. 
Appendix Estimates for year 2005 based on 1995 and 2000 data

[Figure A1 near here]

[Figure A2 near here] 


\section{Figures}
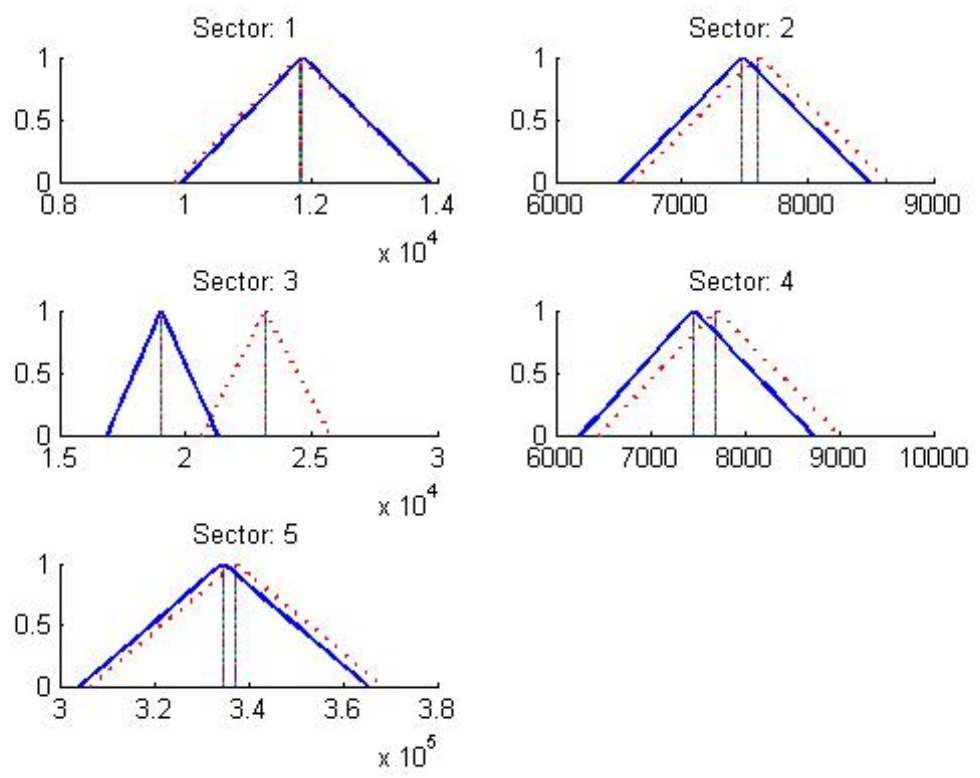

Figure 1 Predicted total output in 2010 for the final demand vector A (solid blue line) and for the final demand vector B (dashed red line).
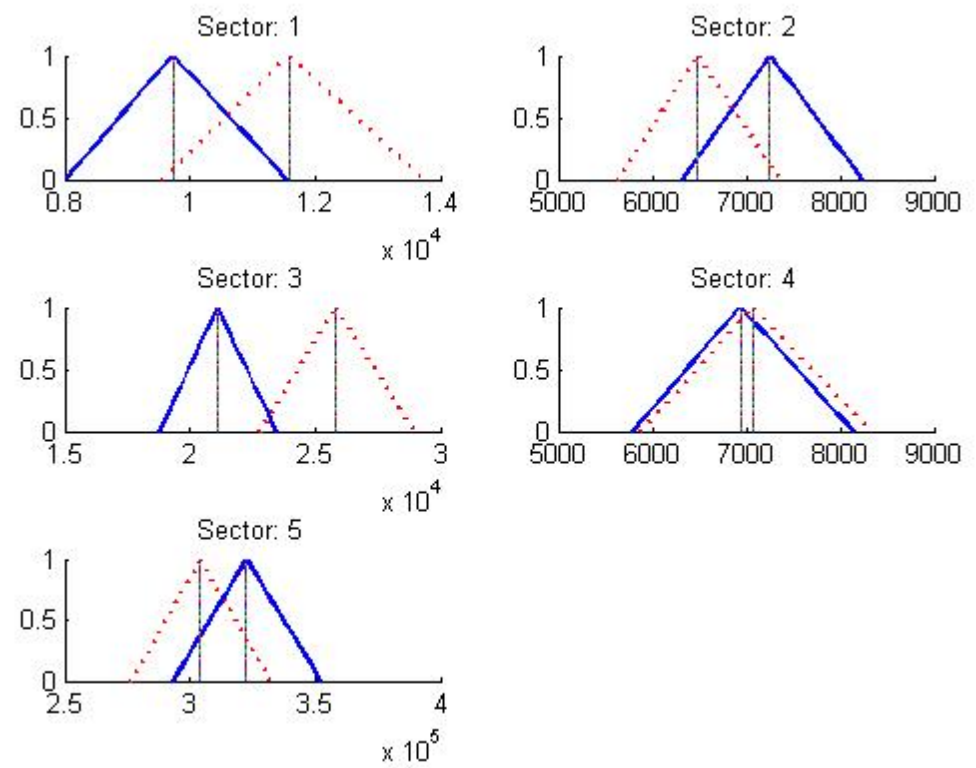

Figure A1 Observed (solid blue line) and predicted (dashed red line) total output for 2005 (year 1995 fuzzy aij). 

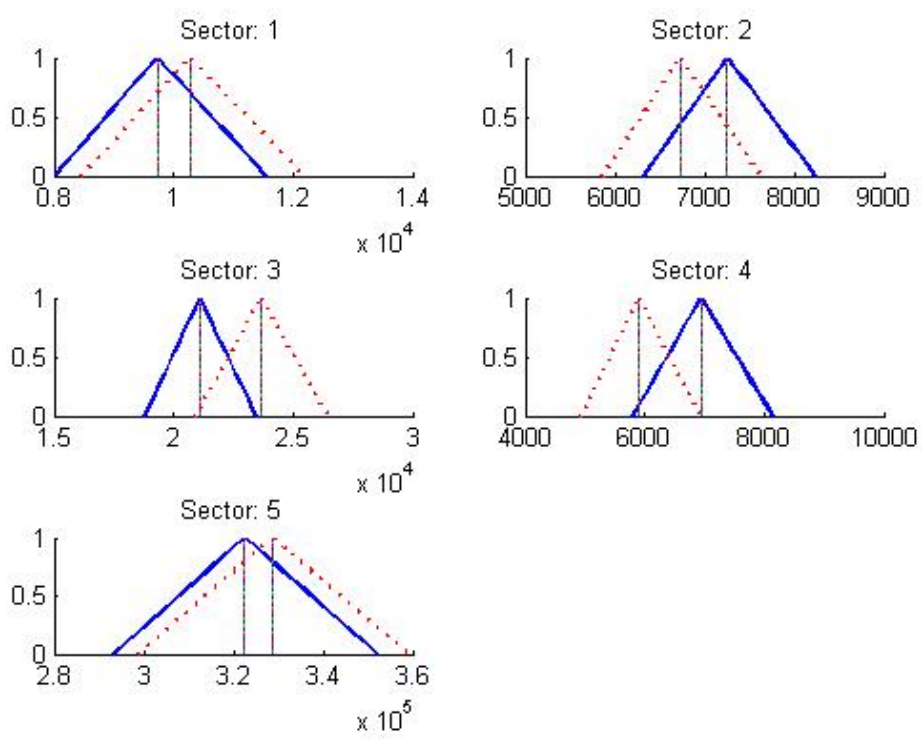

Figure A2 Observed (solid line) and predicted (dashed line) total output for 2005 (year 2000 fuzzy $\left.a_{i j}\right)$. 


\section{Tables}

Table 1 An input-output table

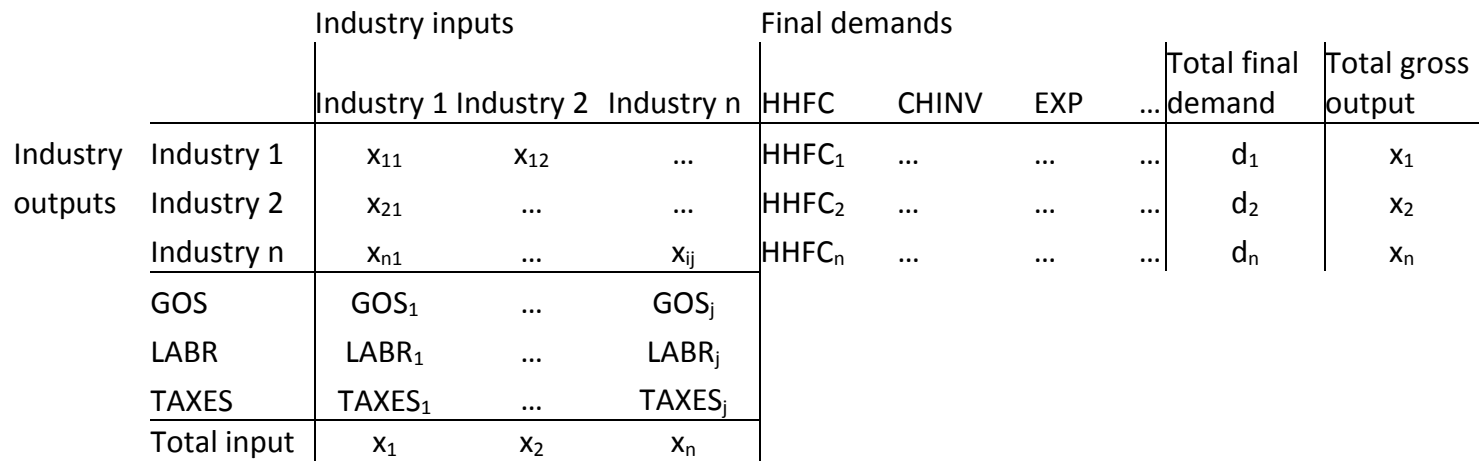

Table 2 Technical coefficients, $a_{i j}$, and the volume of purchases from other industries by the pulp, paper, printing and publishing industry in Brazil.

\begin{tabular}{|c|c|c|c|c|c|c|c|c|}
\hline 1995 & $\begin{array}{l}\text { Million } \\
\text { USD }\end{array}$ & $a_{i j}$ & 2000 & $\begin{array}{l}\text { Million } \\
\text { USD }\end{array}$ & $a_{i j}$ & 2005 & $\begin{array}{l}\text { Million } \\
\text { USD }\end{array}$ & $a_{i j}$ \\
\hline \multicolumn{2}{|c|}{ Pulp, paper etc5133 } & 0.272 & \multicolumn{2}{|c|}{ Pulp, paper etc6837 } & 0.255 & \multicolumn{2}{|c|}{ Pulp, paper etc5640 } & 0.186 \\
\hline Chemicals & 1341 & 0.071 & Chemicals & 1688 & 0.063 & Chemicals & 2463 & 0.081 \\
\hline Wholesale & 1116 & 0.059 & Wholesale & 1581 & 0.059 & Forestry & 1784 & 0.059 \\
\hline Public admin. & 1009 & 0.053 & Public admin. & 816 & 0.030 & Electricity & 1163 & 0.038 \\
\hline Finance & 656 & 0.035 & Electricity & 772 & 0.029 & Wholesale & 1158 & 0.038 \\
\hline Electricity & 488 & 0.026 & Finance & 717 & 0.027 & Other business & $s 1062$ & 0.035 \\
\hline Forestry & 465 & 0.025 & Petroleum & 526 & 0.020 & Transport & 954 & 0.031 \\
\hline Machinery & 395 & 0.021 & Forestry & 505 & 0.019 & Rubber & 728 & 0.024 \\
\hline Transport & 325 & 0.017 & Machinery & 474 & 0.018 & Finance & 671 & 0.022 \\
\hline Petroleum & 319 & 0.017 & Telecomm. & 441 & 0.016 & Machinery & 350 & 0.012 \\
\hline TIDPP & 13032 & 0.691 & TIDPP & 17563 & 0.654 & TIDPP & 19077 & 0.629 \\
\hline GOS & 2552 & 0.135 & GOS & 4835 & 0.180 & GOS & 5778 & 0.191 \\
\hline LABR & 2691 & 0.143 & LABR & 3302 & 0.123 & LABR & 5166 & 0.170 \\
\hline TAXES & 587 & 0.031 & TAXES & 1149 & 0.043 & TAXES & 286 & 0.009 \\
\hline Gross output & 18862 & 1.000 & Gross output & 26848 & 1.000 & Gross output & 30307 & 1.000 \\
\hline
\end{tabular}


Table 3 Technical coefficients, $a_{i j}$, and the volume of purchases from other industries by the pulp, paper, printing and publishing industry in Finland.

\begin{tabular}{|c|c|c|c|c|c|c|c|c|}
\hline 1995 & $\begin{array}{l}\text { Million } \\
\text { USD }\end{array}$ & $a_{i j}$ & 2000 & $\begin{array}{l}\text { Million } \\
\text { USD }\end{array}$ & $a_{i j}$ & 2005 & $\begin{array}{l}\text { Million } \\
\text { USD }\end{array}$ & $a_{i j}$ \\
\hline \multicolumn{2}{|c|}{ Pulp, paper etc6289 } & 0.269 & \multicolumn{2}{|c|}{ Pulp, paper etc5765 } & 0.221 & \multicolumn{2}{|c|}{ Pulp, paper etc4399 } & 0.209 \\
\hline Chemicals & 1438 & 0.062 & Forestry & 1765 & 0.068 & Transport & 1494 & 0.071 \\
\hline Transport & 1242 & 0.053 & Transport & 1657 & 0.063 & Forestry & 1448 & 0.069 \\
\hline Electricity & 1158 & 0.050 & Chemicals & 1475 & 0.056 & Chemicals & 1355 & 0.064 \\
\hline Other busines & s1115 & 0.048 & Other busines & s1033 & 0.040 & Electricity & 964 & 0.046 \\
\hline Forestry & 1096 & 0.047 & Electricity & 941 & 0.036 & Other business & s818 & 0.039 \\
\hline Wood & 923 & 0.039 & Wholesale & 809 & 0.031 & Wholesale & 641 & 0.030 \\
\hline Mining & 320 & 0.014 & Wood & 556 & 0.021 & Machinery & 532 & 0.025 \\
\hline Finance & 277 & 0.012 & Machinery & 531 & 0.020 & Wood & 403 & 0.019 \\
\hline Machinery & 265 & 0.011 & Mining & 430 & 0.016 & Mining & 390 & 0.019 \\
\hline TIDPP & 15556 & 0.666 & TIDPP & 17190 & 0.658 & TIDPP & 14361 & 0.681 \\
\hline GOS & 4422 & 0.189 & GOS & 5183 & 0.198 & GOS & 3089 & 0.147 \\
\hline LABR & 3449 & 0.148 & LABR & 3753 & 0.144 & LABR & 3646 & 0.173 \\
\hline TAXES & -54 & -0.002 & TAXES & -10 & 0.000 & TAXES & -11 & -0.001 \\
\hline Gross output & 23373 & 1.000 & Gross output & 26116 & 1.000 & Gross output & 21085 & 1.000 \\
\hline
\end{tabular}

Table 4 Technical coefficients, $a_{i j}$, and the volume of purchases from other industries by the pulp, paper, printing and publishing industry in the United States.

\begin{tabular}{|c|c|c|c|c|c|c|c|c|}
\hline 1995 & $\begin{array}{l}\text { Million } \\
\text { USD }\end{array}$ & $a_{i j}$ & 2000 & $\begin{array}{l}\text { Million } \\
\text { USD }\end{array}$ & $a_{i j}$ & 2005 & $\begin{array}{l}\text { Million } \\
\text { USD }\end{array}$ & $a_{i j}$ \\
\hline \multicolumn{2}{|c|}{ Pulp, paper etc121 068} & 0.231 & \multicolumn{2}{|c|}{ Pulp, paper etc107 733} & 0.188 & \multicolumn{2}{|c|}{ Pulp, paper etc84 367} & 0.161 \\
\hline Wholesale & 25618 & 0.049 & Wholesale & 26674 & 0.046 & Wholesale & 24999 & 0.048 \\
\hline Chemicals & 17276 & 0.033 & $\mathrm{R} \& \mathrm{D}$ & 20832 & 0.036 & $\mathrm{R} \& \mathrm{D}$ & 20607 & 0.039 \\
\hline Other busines & s16 543 & 0.032 & Other comm. & 19532 & 0.034 & Other comm. & 17093 & 0.033 \\
\hline Transport & 15189 & 0.029 & Transport & 16570 & 0.029 & Transport & 16157 & 0.031 \\
\hline Wood & 11216 & 0.021 & Other business & s15 331 & 0.027 & Chemicals & 13236 & 0.025 \\
\hline Real estate & 9044 & 0.017 & Chemicals & 14686 & 0.026 & Other busines & s13 147 & 0.025 \\
\hline Electricity & 8633 & 0.016 & Finance & 11851 & 0.021 & Finance & 10279 & 0.020 \\
\hline Rubber & 7863 & 0.015 & Office mach. & 10390 & 0.018 & Real estate & 8478 & 0.016 \\
\hline Construction & 5715 & 0.011 & Telecomm. & 8372 & 0.015 & Telecomm. & 7849 & 0.015 \\
\hline TIDPP & 280571 & 0.535 & TIDPP & 324087 & 0.564 & TIDPP & 283440 & 0.542 \\
\hline GOS & 78989 & 0.151 & GOS & 81021 & 0.141 & GOS & 97257 & 0.186 \\
\hline LABR & 160894 & 0.307 & LABR & 165035 & 0.287 & LABR & 137888 & 0.263 \\
\hline TAXES & 4062 & 0.008 & TAXES & 4167 & 0.007 & TAXES & 4727 & 0.009 \\
\hline Gross output & 524515 & 1.000 & Gross output & 574311 & 1.000 & Gross output & 523312 & 1.000 \\
\hline
\end{tabular}


Table 5 The volume of sales from the pulp, paper, printing and publishing industry to other industries in Brazil.

\begin{tabular}{lll|lll|lll}
\hline 1995 & $\begin{array}{l}\text { Million } \\
\text { USD }\end{array}$ & $\begin{array}{l}\text { \% of gross } \\
\text { output }\end{array}$ & 2000 & $\begin{array}{l}\text { Million } \\
\text { USD }\end{array}$ & $\begin{array}{l}\text { \% of gross } \\
\text { output }\end{array}$ & 2005 & $\begin{array}{l}\text { Million } \\
\text { USD }\end{array}$ & $\begin{array}{l}\% \text { of gross } \\
\text { output }\end{array}$ \\
\hline Pulp, paper etc & 5133 & $27 \%$ & Pulp, paper etc & 6837 & $25 \%$ & Pulp, paper etc 5640 & $19 \%$ \\
Public admin. & 2143 & $11 \%$ & Other business & 2448 & $9 \%$ & Other business 3832 & $13 \%$ \\
Other business & 1448 & $8 \%$ & Public admin. & 2218 & $8 \%$ & Finance & 1785 & $6 \%$ \\
Wholesale & 1334 & $7 \%$ & Wholesale & 1922 & $7 \%$ & Food & 1185 & $4 \%$ \\
Food & 1281 & $7 \%$ & Food & 1793 & $7 \%$ & Telecomm. & 1090 & $4 \%$ \\
Chemicals & 484 & $3 \%$ & Chemicals & 715 & $3 \%$ & Wholesale & 1007 & $3 \%$ \\
Other comm. & 325 & $2 \%$ & Other comm. & 547 & $2 \%$ & Chemicals & 982 & $3 \%$ \\
Finance & 313 & $2 \%$ & Computer & 504 & $2 \%$ & Other comm. & 844 & $3 \%$ \\
Textiles & 304 & $2 \%$ & Textiles & 383 & $1 \%$ & Public admin. & 668 & $2 \%$ \\
Computer & 303 & $2 \%$ & Other non-met. & 358 & $1 \%$ & Health & 589 & $2 \%$ \\
\hline TIC & 15485 & $82 \%$ & TIC & 21493 & $80 \%$ & TIC & 21376 & $71 \%$ \\
\hline HNG & 2469 & $13 \%$ & HNG & 4155 & $15 \%$ & HNG & 6318 & $21 \%$ \\
GFCF & 49 & $0 \%$ & GFCF & 44 & $0 \%$ & GFCF & 36 & $0 \%$ \\
CINV & -45 & $0 \%$ & CINV & 134 & $0 \%$ & CINV & 68 & $0 \%$ \\
EXPORT & 2026 & $11 \%$ & EXPORT & 2399 & $9 \%$ & EXPORT & 3704 & $12 \%$ \\
IMPORT & 1122 & $6 \%$ & IMPORT & 1377 & $5 \%$ & IMPORT & 1194 & $4 \%$ \\
\hline Gross output & 18862 & & Gross output & 26848 & & Gross output & 30307 &
\end{tabular}

Table 6 The volume of sales from the pulp, paper, printing and publishing industry to other industries in Finland.

\begin{tabular}{|c|c|c|c|c|c|c|c|c|}
\hline 1995 & $\begin{array}{l}\text { Million } \\
\text { USD }\end{array}$ & $\begin{array}{l}\% \text { of gross } \\
\text { output }\end{array}$ & 2000 & $\begin{array}{l}\text { Million } \\
\text { USD }\end{array}$ & $\begin{array}{ll}\begin{array}{l}\% \text { of gross } \\
\text { output }\end{array} \\
\end{array}$ & 2005 & $\begin{array}{l}\text { Million } \\
\text { USD }\end{array}$ & $\begin{array}{ll}\% \text { of gross } \\
\text { output }\end{array}$ \\
\hline Pulp, paper etc & 6289 & $27 \%$ & Pulp, paper etc & 5765 & $22 \%$ & \multicolumn{2}{|c|}{ Pulp, paper etc4399 } & $21 \%$ \\
\hline Wholesale & 907 & $4 \%$ & Wholesale & 964 & $4 \%$ & Wholesale & 1058 & $5 \%$ \\
\hline Food & 448 & $2 \%$ & Other comm. & 593 & $2 \%$ & ICT equip. & 573 & $3 \%$ \\
\hline Other comm. & 425 & $2 \%$ & ICT equip. & 534 & $2 \%$ & Other comm. & 530 & $3 \%$ \\
\hline Other business & 362 & $2 \%$ & Other business & 467 & $2 \%$ & Other business & 504 & $2 \%$ \\
\hline Chemicals & 306 & $1 \%$ & Food & 465 & $2 \%$ & Food & 353 & $2 \%$ \\
\hline Hotels & 299 & $1 \%$ & Real estate & 313 & $1 \%$ & Real estate & 249 & $1 \%$ \\
\hline Public admin. & 251 & $1 \%$ & Chemicals & 279 & $1 \%$ & Public admin. & 211 & $1 \%$ \\
\hline Transport & 250 & $1 \%$ & Public admin. & 237 & $1 \%$ & Chemicals & 203 & $1 \%$ \\
\hline Real estate & 185 & $1 \%$ & Machinery & 220 & $1 \%$ & Machinery & 190 & $1 \%$ \\
\hline TIC & 11494 & $49 \%$ & TIC & 11949 & $46 \%$ & TIC & 9931 & $47 \%$ \\
\hline HNG & 1276 & $5 \%$ & HNG & 1306 & $5 \%$ & HNG & 1678 & $8 \%$ \\
\hline GFCF & 6 & $0 \%$ & GFCF & 35 & $0 \%$ & GFCF & 23 & $0 \%$ \\
\hline CINV & 137 & $1 \%$ & CINV & 98 & $0 \%$ & CINV & 279 & $1 \%$ \\
\hline EXPORT & 11345 & $49 \%$ & EXPORT & 13885 & $53 \%$ & EXPORT & 10470 & $50 \%$ \\
\hline IMPORT & 886 & $4 \%$ & IMPORT & 1158 & $4 \%$ & IMPORT & 1295 & $6 \%$ \\
\hline Gross output & 23373 & & Gross output & 26116 & & Gross output & 21085 & \\
\hline
\end{tabular}


Table 7 The volume of sales from the pulp, paper, printing and publishing industry to other industries in the United States.

\begin{tabular}{lll|lll|lll}
\hline 1995 & $\begin{array}{l}\text { Million } \\
\text { USD }\end{array}$ & $\begin{array}{l}\% \text { of gross } \\
\text { output }\end{array}$ & 2000 & $\begin{array}{l}\text { Million } \\
\text { USD }\end{array}$ & $\begin{array}{l}\% \text { of gross } \\
\text { output }\end{array}$ & 2005 & $\begin{array}{l}\text { Million } \\
\text { USD }\end{array}$ & $\begin{array}{l}\% \text { of gross } \\
\text { output }\end{array}$ \\
\hline Pulp, paper etc 121068 & $23 \%$ & Pulp, paper etc 107733 & $19 \%$ & Pulp, paper etc 84367 & $16 \%$ \\
Other business & 94443 & $18 \%$ & Public admin. $\begin{array}{l}33690 \\
\text { Wholesale }\end{array}$ & 41928 & $8 \%$ & $6 \%$ & Public admin. 36576 & $7 \%$ \\
Food & 23155 & $4 \%$ & Other comm. & 29175 & $5 \%$ & Other comm. 26619 & $5 \%$ \\
Health & 21233 & $4 \%$ & Wholesale & 28367 & $5 \%$ & Wholesale & 24286 & $5 \%$ \\
Finance & 16643 & $3 \%$ & Food & 24591 & $4 \%$ & Food & 22352 & $4 \%$ \\
Other comm. & 15056 & $3 \%$ & Health & 18603 & $3 \%$ & Health & 16475 & $3 \%$ \\
Education & 13967 & $3 \%$ & Office mach. & 17186 & $3 \%$ & Office mach. & 11744 & $2 \%$ \\
Construction & 13084 & $2 \%$ & Finance & 13055 & $2 \%$ & Finance & 9837 & $2 \%$ \\
Telecomm. & 10712 & $2 \%$ & Chemicals & 11068 & $2 \%$ & Chemicals & 9778 & $2 \%$ \\
\hline TIC & 448137 & $85 \%$ & TIC & 401162 & $70 \%$ & TIC & 349721 & $67 \%$ \\
\hline HNG & 72610 & $14 \%$ & HNG & 93738 & $16 \%$ & HNG & 92546 & $18 \%$ \\
GFCF & 2830 & $1 \%$ & GFCF & 72817 & $13 \%$ & GFCF & 79949 & $15 \%$ \\
CINV & 1854 & $0 \%$ & CINV & 3484 & $1 \%$ & CINV & 1564 & $0 \%$ \\
EXPORT & 23754 & $5 \%$ & EXPORT & 31967 & $6 \%$ & EXPORT & 30508 & $6 \%$ \\
IMPORT & 24670 & $5 \%$ & IMPORT & 28857 & $5 \%$ & IMPORT & 30975 & $6 \%$ \\
\hline Gross output & 524515 & & Gross output & 574311 & & Gross output & 523312 & \\
\hline
\end{tabular}

Table 8 Five sector input-output tables of Finland in 1995, 2000 and 2005.

\begin{tabular}{|c|c|c|c|c|c|c|c|c|c|c|c|c|}
\hline 1995 & Forestry & Wood & $\begin{array}{l}\text { Pulp, } \\
\text { paper }\end{array}$ & Electr. & Other & HNG & GFCF & CHINV & EXPORT & IMPORT & FD & \begin{tabular}{|l} 
Total \\
output
\end{tabular} \\
\hline Forestry & 1802 & 1864 & 1096 & 1 & 3665 & 1274 & 277 & 426 & 530 & 986 & 1521 & 9949 \\
\hline Wood & 13 & 473 & 923 & 31 & 1275 & 52 & 1 & 24 & 3054 & 603 & 2529 & 5243 \\
\hline Pulp, paper & 116 & 97 & 6289 & 105 & 4887 & 1276 & 6 & 137 & 11345 & 886 & 11879 & 23373 \\
\hline Electricity & 181 & 126 & 1158 & 193 & 3089 & 1164 & 69 & 0 & 27 & 206 & 1055 & 5803 \\
\hline Other & 2434 & 1127 & 5936 & 2020 & 86309 & 84595 & 20880 & 1339 & 33709 & 35576 & 104947 & 202772 \\
\hline 2000 & Forestry & Wood & $\begin{array}{l}\text { Pulp, } \\
\text { paper }\end{array}$ & Electr. & Other & HNG & GFCF & CHINV & EXPORT & IMPORT & FD & \begin{tabular}{|l} 
Total \\
output
\end{tabular} \\
\hline Forestry & 2027 & 2174 & 1765 & 13 & 3446 & 1252 & 142 & 143 & 639 & 1472 & 704 & 10129 \\
\hline Wood & 6 & 827 & 556 & 106 & 2034 & 33 & 8 & 21 & 3880 & 353 & 3589 & 7120 \\
\hline Pulp, paper & 52 & 132 & 5765 & 107 & 5893 & 1306 & 35 & 98 & 13885 & 1158 & 14167 & 26116 \\
\hline Electricity & 171 & 126 & 941 & 82 & 3473 & 761 & 24 & 0 & 17 & 105 & 697 & 5491 \\
\hline Other & 2374 & 2125 & 8042 & 2496 & 129063 & 100559 & 31390 & 1167 & 53354 & 53040 & 133431 & 277531 \\
\hline 2005 & Forestry & Wood & $\begin{array}{l}\text { Pulp, } \\
\text { paper }\end{array}$ & Electr. & Other & HNG & GFCF & CHINV & EXPORT & IMPORT & FD & \begin{tabular}{|l} 
Total \\
output
\end{tabular} \\
\hline$\overline{\text { Forestry }}$ & 2184 & 2171 & 1448 & 42 & 3412 & 1404 & 235 & 125 & 598 & 1894 & 469 & 9726 \\
\hline Wood & 12 & 1076 & 403 & 165 & 2687 & 62 & 16 & -33 & 3443 & 576 & 2912 & 7255 \\
\hline Pulp, paper & 24 & 80 & 4399 & 71 & 5356 & 1678 & 23 & 279 & 10470 & 1295 & 11154 & 21085 \\
\hline Electricity & 101 & 174 & 964 & 181 & 4961 & 1053 & 32 & 3 & 40 & 572 & 556 & 6937 \\
\hline Other & 2436 & 2051 & 7041 & 2622 & 146920 & 123927 & 34082 & 2926 & 65788 & 65273 & 161450 & 322521 \\
\hline
\end{tabular}


Table 9 Estimates of each component of final demand compared to the year 2005.

\begin{tabular}{|c|c|c|c|c|c|}
\hline & \multicolumn{5}{|c|}{ Component of final demand } \\
\hline Industry & HNG & GFCF & CHINV & Exports & Imports \\
\hline Forestry & $\mathrm{xx}$ & $\mathrm{x}$ & $\mathrm{x}$ & $\mathrm{xx}$ & $\begin{array}{l}\text { A: } \\
\text { Are assumed to decrease } \\
\text { by } 80 \% \\
\text { ( } 50 \% \text { decrease in imports } \\
\text { compared to the year } \\
2009) \\
\text { B: } \\
\text { B: } \\
\text { Are assumed to decrease } \\
\text { by } 59 \% \\
\text { (imports remain at the } \\
2009 \text { level) }\end{array}$ \\
\hline Wood & $\mathrm{xx}$ & $\mathrm{x}$ & $\mathrm{x}$ & $\mathrm{xx}$ & $\mathrm{xx}$ \\
\hline Pulp, paper & $\mathrm{xx}$ & $\mathrm{x}$ & $\mathrm{x}$ & $\begin{array}{l}\text { A: } \\
\text { Are assumed to decrease } \\
\text { by } 15 \% \text { (demand for } \\
\text { Finnish paper and pulp } \\
\text { collapses compared to the } \\
\text { year } 2008 \text { and prices } \\
\text { remain at low levels ) } \\
\text { B: } \\
\text { Are assumed to increase } \\
\text { by } 15 \% \text { (demand } \\
\text { increases slightly } \\
\text { compared to the year } \\
2008 \quad \text { (environmental } \\
\text { catastrophes e.g. in Chile } \\
\text { and supply uncertainty)) }\end{array}$ & $\begin{array}{l}\text { A: } \\
\text { Are assumed to increase } \\
\text { by } 25 \% \text { (imports } \\
\text { increased by 15\% } \\
\text { between } 2005 \text { and 2008) } \\
\text { B: } \\
\text { Are assumed to increase } \\
\text { by } 20 \% \\
\text { (more roundwood is } \\
\text { imported compared to the } \\
\text { scenario A ) }\end{array}$ \\
\hline Electricity & \begin{tabular}{|l|} 
A\&B: \\
Is assumed to increase by \\
$35 \%$ \\
(households electricity \\
prices increased by 25- \\
$45 \%$ between 2005 and \\
2009 )
\end{tabular} & $\mathrm{x}$ & $\mathrm{x}$ & $\begin{array}{l}\text { A\& B: } \\
\text { Are assumed to increase } \\
\text { by } 300 \% \\
\text { (exports nearly trebled } \\
\text { between } 2005 \text { and 2009) }\end{array}$ & $\begin{array}{l}\text { A\&B: } \\
\text { Are assumed to increase } \\
\text { by } 10 \%\end{array}$ \\
\hline Other & $\mathrm{xx}$ & $\mathrm{x}$ & $\mathrm{x}$ & $\mathrm{xx}$ & $\mathrm{xx}$ \\
\hline
\end{tabular}

$x$ indicates that the component is assumed to be the same as in 2005

$x x$ indicates that the component is assumed to increase by $4 \%$, which is the expected GDP growth between 2005 and 2010 
Table 102010 final demand scenarios for Finland.

\begin{tabular}{lllll}
\hline Sector & $\begin{array}{l}\text { Final } \\
\text { demand } \\
\text { 2010 A }\end{array}$ & $\begin{array}{l}\text { Percent } \\
\text { change }\end{array}$ & $\begin{array}{l}\text { Final } \\
\text { demand } \\
2010 \mathrm{~B}\end{array}$ & $\begin{array}{l}\text { Percent } \\
\text { change }\end{array}$ \\
\hline 1. Forestry & 2064 & $340 \%$ & 1666 & $255 \%$ \\
2. Wood & 3029 & $4 \%$ & 3029 & $4 \%$ \\
3. Pulp, paper. & 9327 & $-16 \%$ & 12532 & $12 \%$ \\
4. Electricity & 947 & $70 \%$ & 947 & $70 \%$ \\
5. Other & 167908 & $4 \%$ & 167908 & $4 \%$ \\
\hline
\end{tabular}

Table 11 Predicted total output in 2010 for the final demand vectors A and B. Fuzzy 2005 $a_{i j}$ coefficients and fuzzy demand vectors were used.

\begin{tabular}{lll}
\hline Sector & $\begin{array}{l}\mathrm{X}_{\mathrm{A}} \\
\text { (million USD) }\end{array}$ & $\begin{array}{l}\mathrm{X}_{\mathrm{B}} \\
\text { (million USD) }\end{array}$ \\
\hline $\begin{array}{l}\text { 1. Forestry } \\
\text { 2. Wood }\end{array}$ & {$\left[\begin{array}{llll}11860 & 1890 & 2000\end{array}\right]$} & {$\left[\begin{array}{lll}11800 & 1930 & 2040\end{array}\right]$} \\
3. Pulp, paper. & {$\left[\begin{array}{llll}19050 & 2160 & 2230\end{array}\right]$} & {$\left[\begin{array}{lll}7610 & 990 & 1030\end{array}\right]$} \\
4. Electricity & {$\left[\begin{array}{llll}7460 & 1190 & 1260\end{array}\right]$} & {$\left[\begin{array}{lll}23160 & 2500 & 2570\end{array}\right]$} \\
5. Other & {$\left[\begin{array}{llll}334600 & 30150 & 30600\end{array}\right]$} & {$\left[\begin{array}{llll}737320 & 30630 & 31100\end{array}\right]$} \\
\hline
\end{tabular}

Table 12 Predicted inter-industry transactions for 2010.

Final demad scenario A

(million USD)

\begin{tabular}{|c|c|c|c|c|c|c|c|c|c|c|c|c|c|c|}
\hline \multicolumn{3}{|c|}{ 1. Forestry } & \multicolumn{3}{|c|}{ 2. Wood } & \multicolumn{3}{|c|}{ 3. Pulp, paper } & \multicolumn{3}{|c|}{ 4. Electricity } & \multicolumn{3}{|l|}{ 5. Other } \\
\hline 1. $[2660$ & 510 & 570] & {$[2240$} & 370 & 400] & {$[1310$} & 200 & 210] & {$[50$} & 10 & 10] & {$[3540$} & 450 & 480] \\
\hline 2. [20 & 0 & 0] & {$[1110$} & 180 & 200] & {$[360$} & 50 & 60] & {$[180$} & 30 & 40] & {$[2790$} & 350 & 380] \\
\hline 3. [30 & 10 & 10] & {$[80$} & 10 & 10] & {$[3970$} & 590 & 640] & {$[80$} & 10 & 20] & {$[5560$} & 700 & 750] \\
\hline 4. $[120$ & 20 & 30] & {$[180$} & 30 & 30] & {$[870$} & 130 & 140] & {$[190$} & 40 & 40] & {$[5150$} & 650 & 700] \\
\hline 5. $[2970$ & 570 & 640] & {$[2120$} & 350 & 380] & {$[6360$} & 950 & 1030] & {$[2820$} & 550 & 610] & [152420 & 19280 & 20590] \\
\hline
\end{tabular}

Final demad scenario B (million USD)

\begin{tabular}{|c|c|c|c|c|c|c|c|c|c|c|c|c|c|c|}
\hline \multicolumn{3}{|c|}{ 1. Forestry } & \multicolumn{3}{|c|}{ 2. Wood } & \multicolumn{3}{|c|}{ 3. Pulp, paper } & \multicolumn{3}{|c|}{ 4. Electricity } & \multicolumn{3}{|l|}{ 5. Other } \\
\hline 1. $[2650$ & 520 & 580] & {$[2280$} & 370 & 410] & {$[1590$} & 230 & 250] & {$[50$} & 10 & 10] & {$[3570$} & 450 & 480] \\
\hline 2. [10 & 0 & 0] & {$[1130$} & 190 & 200] & {$[440$} & 60 & 70] & {$[180$} & 40 & 40] & {$[2810$} & 360 & 380] \\
\hline 3. [30 & 10 & 10] & {$[80$} & 10 & 20] & {$[4830$} & 690 & 750] & {$[80$} & 20 & 20] & {$[5600$} & 710 & $760]$ \\
\hline 4. $[120$ & 20 & 30] & {$[180$} & 30 & 30] & [1060 & 150 & 160] & {$[200$} & 40 & 40] & {$[5190$} & 660 & 710] \\
\hline 5. [2960 & 580 & 650] & {$[2150$} & 350 & 390] & {$[7730$} & 1110 & 1200] & {$[2910$} & 570 & 630] & [153660 & 19540 & 20880] \\
\hline
\end{tabular}

